\title{
江戸時代後期の三陸沖地震・津波に関する 一漁民の手記について
}

遠 藤 匡 俊

『万ふしきの事控覚帳』は石浜（現，宮城県牡鹿郡女 川町石浜)在の漁民，勇蔵が記した，寛政 12 年(1800) から嘉永 7 年（1854）にか忖ての手記である。その内 容は漁業を中心としたものであるが，石浜に括ける地 震と津波の記載もある。すでに他地区の史料を基に報 告されている現象ではあるが，本手記は史料としてま だ引用されていないと思われるので報告する。その記 載は次の通りである。

(I)「天保六末の年六月廿四日昼の八ッ時大地震ゆ り申候四十三年程先丑の年の地震程には無御座候得共 大地震なり」

(II)「同年号 (天保八) 十月十一日夜の九ッ時より 大津浪入込申候て大騒き仕候此時は地震もゆらすに津 浪斗り入込申候四十五年程先の寛政時代の津浪御座 候」

これを他史料による報告と比較したものが第 1 表であ る。

第 1 表 三陸沖地震・津波の規模

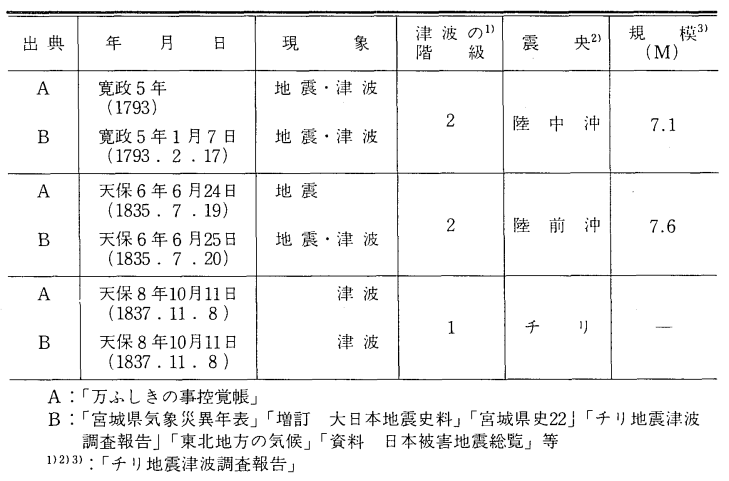

(a) 寛政 5 年 (1793)

「四十三年程先开の年」(I) 掞よび「四十五年程先の 寛政時代」(II) といら記事から，寛政 5 年と思われる。
月日の記載は無いが, 1 月 7 日の陸前・陸中に㧍ける地 震・津波であると思わ机る。津波が生じた範囲は岩手 県沿岸（宇佐美，1975）あるいは宮城県北の桃生郡雄 勝沿岸（仙台管区気象台，1963）といわれるが，さら に南の石浜でも生じたことがわかる。

(b) 天保 6 年 6 月 24 日 (1835.7.19)

手記には24日に大地震があったと記されているが, 同日の地震の記録は報告されていない。ただし，翌 25 日に大地震のあったことは多くの資料に記されている (第 1 表)。仙台藩領では津波が生じたとされるが，手 記には津波の記載が無い。日付の 24 日は勇蔵の記憶違 いであるかもしれない。また，寛政 5 年の地震よりは 小規模であったと手記にあるが，このことは他資料に よる震央・規模の推定（第 1 表）と矛盾するょらに思 われる。

(c) 天保 8 年 10 月 11 日 (1837.11.8)

手記には，地震が無く津波のみが生じたとある。こ の津波の原因と思われる地震は日本付近で見い出し得 ず，チリで生じた地震によるもの（仙台管区気象台, 1961）と推定される。

（東北大学・院）

(1984 年 4 月 19 日 受理)

\section{文献}

宮城県史編纂委員会 (1952)：万ふしきの事控覚帳。30 頁.

宮城県史編纂委員会 (1962): 宮城県史. 22, 499 頁. 文部省震災豫防評議会（1976）：増訂 大日本地震史 料。3, 鳴鳳社, 945 頁.

仙台管区気象台 (1951): 東北地方の気候. 381 頁.

仙台管区気象台（1961）：チリ地震津波調査報告.91 頁.

仙台管区気象台 (1963)：宮城県気象災異年表. 120 頁. 宇佐美龍夫 (1975) : 資料 日本被害地震総覧。東京大 学出版会, 327 頁.

Materials Concerning Earthquakes and Tsunamis along the

Sanriku Coast in the Late Edo Era

Masatoshi ENDo 